\title{
Future scenarios as a tool for collaboration in forest communities
}

\author{
K. Evans ${ }^{1}$, W. de Jong ${ }^{2}$, and P. Cronkleton ${ }^{3}$ \\ ${ }^{1}$ Consultant, Center for International Forestry Research, New Orleans, USA \\ ${ }^{2}$ Professor, Center for Integrated Area Studies, Kyoto University, Japan \\ ${ }^{3}$ Scientist, Center for International Forestry Research, Santa Cruz, Bolivia
}

Received: 30 May 2007 - Revised: 15 September 2008 - Accepted: 18 September 2008 - Published: 14 October 2008

\begin{abstract}
Forest devolution is meant to provide communities with greater decision-making power over the use and future of tropical forests. However, devolution policies have not always had the intended effect; in some cases they have caused or furthered the disenfranchisement of the poor, the creation of open access conditions, resource conflict and forest degradation. These problems are likely to arise when forest communities are at a disadvantage when interacting with other local players and are unprepared for their new opportunities and responsibilities due to their physical remoteness, cultural isolation, low literacy rates or lack of experience in formal planning and negotiation. This paper discusses how a participatory method to facilitate thinking about the future - called future scenarios - can help change the way forest communities and local governments interact. The paper reviews a growing body of literature on future scenarios and shares first-hand experiences with future scenarios in forest communities in the northern Bolivian Amazon and the central provinces of Vietnam. It finds that under the right conditions, the use of future scenarios allows forest communities to collaborate more effectively with local government, better assume responsibilities when given control over forests under devolution schemes and self-organize to benefit from the opportunities that communal control over forests offers. Future scenarios help communities think about dependency, vulnerabilities and ways to prepare for the future; the methods develop organizational capacity and encourage internal democratic processes and planning. Community leaders become more vocal and assertive in meetings with local government, and marginalized groups within communities, such as women or the poorest segments, make their voices heard. However, the methods are less effective when facilitation skills are not available or where government or other interests are threatened by local constituents. Future scenarios are not without their pitfalls and do not work in all situations, but given the appropriate context they can create "break-through moments" that improve collaboration between communities and local officials.
\end{abstract}

Keywords. Future scenarios, participatory methods, forest-dependent communities, forest devolution, decentralization

\section{Table of Contents}

1 Introduction

2 Future scenarios and environmental decision making

3 Improving collaboration between local governments and forest communities

4 Future scenarios' limitations

5 Conclusions

Correspondence to: W. de Jong

(wdejong@ cias.kyoto-u.ac.jp)

Published by Copernicus Publications on behalf of the Institut Veolia Environnement. 


\section{Introduction}

A dramatic transformation is occurring in tropical forests. Through a process known as forest devolution, governments are transferring legal forest usage and tenure rights to local communities (Sunderlin et al., 2008; RRI, 2008). The process will affect the future of millions of hectares of tropical forest and the livelihoods of millions of people living in or near forests (Sunderlin et al., 2005). There are several reasons to return forests to the people who have historically relied on them for their livelihoods and held customary ownership claims that were later usurped by governments or the private sector. First, it is hoped that forest devolution will address the consequences of unsustainable forest management by central government or private enterprises (Edmunds and Wollenberg, 2003; Arnold, 2001). Politicians and businesses tend to focus on short-term benefits; communities with livelihoods linked to forests have a stake in guaranteeing that forests are available for future generations, and they have an incentive to be responsible custodians (Evans et al., 2006; Cronkleton et al., 2008). Second, when communities are owners, they are better positioned to capture benefits from the forests, which can improve their quality of life and reduce rural poverty (RRI, 2008; Colfer, 2005; Colfer and Byron, 2001).

Forest devolution, while ambitious, is possibly the best chance to save tropical forests and improve the lives of some of the world's poorest people. The reality, however, is that under forest devolution, rights are being transferred to the people who are often the most marginalized and least empowered to defend themselves. Powerful forces can step in and take the forest back by fiat, fraud or force. While forest devolution has seen encouraging successes (Barton et al., 2005; Wiley, 2002; Enters et al., 2000), failures - where local people did not benefit from newly owned forests and unsustainable forest exploitation continued or increased - have been common too (Edmunds and Wollenberg, 2003; Stocks, 2005; Stearman, 2006; RRI, 2008). The reasons for failure vary, but in many cases forest devolution programs were developed with little understanding of the challenges of empowering marginalized forest communities. Forest communities are frequently isolated, with small, dispersed populations and a history of paternalistic control or marginalization by government or local power holders. Community members often have limited or no formal education and illiteracy rates are high. Transparent processes, democratic decision making, consensus building, systematic documentation of needs and collective action may not be part of the local institutional culture. As a consequence, community members often lack the skills and experience to articulate needs and demands to local authorities. Clearly the problem does not lie solely with the communities: equally problematic is the reluctance by forest specialists and government officials to give communities a true voice in decision making (Colfer, 2005; Chapin, 2004). Government officials, private economic interests and other stakeholders often ignore communities, co-opting rights and resources that should legally be transferred to local people (Colfer, 2004, 2005; Lynam et al., 2007; CIFOR, 2007; RRI, 2008).

For forest devolution to succeed, residents of forest communities must be able to participate effectively in decision making, they must be able to engage other stakeholders and express their perspectives, and they must be able to collaborate and negotiate effectively with other actors. Over the last decade, forest devolution advocates have developed methods for facilitating collaborative forest management and democratic participation by forest communities (Davis-Case, 1990; Holman and Devane, 1999; Colfer, 2005; Evans et al., 2006; Lynam et al., 2007; CIFOR, 2007). Promotion of collaborative forest management has led to legal and policy changes to accommodate multi-stakeholder forest management (Buck et al., 2001; Fisher, 1995). The reforms have encouraged the adoption of participatory decision making and planning methods that advance community participation and consideration of local people's views and preferences in forestry related decision making (Lynam et al., 2007).

In this article we explore one suite of methods, called future scenarios, that has been introduced in forest communities to help people identify needs, anticipate change, reach consensus, articulate communal expectations and communicate them easily to local government or forest authorities as an important first step towards fair, transparent and participatory forest related decision making. We try to answer the following questions: Can future scenarios help prepare communities for new responsibilities under forest devolution? Can future scenarios help improve collaboration between communities and local government?

\section{Future scenarios and environmental decision making}

Future scenarios were originally developed for military planning purposes and later adopted by the business world (Wack, 1985; van der Heijden, 1996); they have emerged since the late 1990s as an important tool in environmental analysis and policy formulation (Bierman et al., 2003; Biggs et al., 2007; Alcamo, 2001; Carpenter et al., 2006; Patel et al., 2006). In the 1990s, advocates of community-based forest management recognized the steep obstacles that forest communities faced in sustainable forest management and acknowledged that tools and skills were necessary to help them collaborate on a more equal footing with other - typically more powerful - stakeholders. The Adaptive Collaborative Management (ACM) project, developed by CIFOR, focused on understanding the role of collaboration in sustainable community forest management and developing mechanisms to enhance fair and productive communication and negotiation between marginalized forest users and more powerful local decision makers (Colfer, 2005). Wollenberg et al. (1999, 2000) 
identified future scenarios as a tool that could be adapted to the community forest context.

Future scenarios are workshop-based activities where people with diverse interests can come together to anticipate, envision and plan for the future. The methods stimulate reflection and dialogue among stakeholders - essential elements of participatory planning and productive collaboration - and they create interest in continued involvement in planning processes. They are mental exercises to consider plausible future situations, imagine potential outcomes and explore contingencies (Evans et al., 2006). Advocates claim that when executed correctly, participants in future scenarios sessions consider alternatives and reflect on chains of events to avoid conflicts and costly mistakes that are likely without a welldefined, systematic process (van der Heijden, 1996). They can also help participants think about an ideal future, articulate hopes and desires, share them in a group setting and arrive at a consensus about a common vision (Wollenberg et al., 1999; Evans et al., 2006).

In this paper we are concerned with the process of building scenarios and how it can change the way forest communities and local governments think about their world and interact with each other. All people have world views, or mental maps, that are created by their experiences, assumptions, culture, environment, political ideology or interests. While mental maps are useful for structuring their understanding of the world around them, they can be constrictive when thinking about the future (Evans et al., 2006). Something may be thought to be implausible or wrong simply because it has never occurred before, is undesirable or is out of people's control (Ibid.). Scenarios encourage - and sometimes force - people to rewrite their mental maps and consider new understandings of the way the world could work.

Changes in mental maps do not always follow a predictable progressive path; learning can instead take the form of unexpected discoveries, or "break-through moments", when creative thinking opens up the mind to entirely new range of possibilities (Wollenberg et al., 2000). Future scenarios foment break-through moments, generating "imaginative explications of the possibilities" (Brewer, 2007:167). These "break-through moments" arise from the creative process of building the scenarios, which requires input from and discussion with other people. When people of differing perspectives, interests and power work together to develop scenarios, they understand the rationality behind other points of view; they discuss issues that affect them; consensus is not inevitable, but increased understanding leads to communication and collaboration. Scenarios planning thus helps people with conflicting interests recognize that they share a common objective and have a stake in collaborating to reconcile their differences and change attitudes: break-through moments help break down barriers. One well-known example is the Mont Fleur Scenarios project in South Africa, where various feuding political factions gathered together in the postapartheid environment to think about what the future might hold if they put their differences aside and work together $(\mathrm{Fa}-$ hey and Randall, 1997).

Several research groups have independently used future scenarios in action research settings that included forest communities or local people who face similar challenges (Wollenberg et al., 1999, 2000; Nemarundwe et al., 2003; Evans et al., 2006, 2008; Stock et al., 2007; Patel et al., 2006) in a wide range of countries, including Indonesia (Wollenberg et al., 1999, 2007), Ethiopia (Kassa et al., 2008), Thailand (Thongbai et al., 2008) and Peru (Velarde et al., 2007). While the settings were very different, the research groups used future scenarios in similar ways. The approaches included facilitating the construction of visions and strategies of how to achieve various alternative possible future outcomes from current situations (Wollenberg, 1999; Evans et al., 2008; Patel et al., 2006; Velarde et al., 2007).

\section{Improving collaboration between local govern- ments and forest communities}

In our work we wanted to understand if and how future scenarios can improve collaboration between local government and villages in remote tropical forests. We tested future scenarios in two distinct contexts, the northern Bolivian Amazon and central Vietnam (Evans et al., 2008), where dramatic forest devolution and decentralization processes were underway. In Bolivia, municipal governments have a mandate under decentralization reforms to include communities in planning and budgeting. In the northern Bolivian Amazon, municipal governments faced steep challenges in meeting this mandate. Communities are exceptionally remote and there is little communication infrastructure. Education levels are low and illiteracy approaches $90 \%$ in some villages (Ruiz, 2005; Gottwald, 2006). Furthermore, communities have only recently emerged from a patronage system, where large landholders employed rural people first as rubber collectors and then as Brazil nut harvesters under debt peonage arrangements.

The decentralization reforms of the 1990s promised that local people would receive new rights over forest lands and opportunities to participate in local decision-making. However, in many cases, landholders reclaimed political control after decentralization and forest devolution when they became mayors and governors. The first mayors of the municipality where we worked had been the principal landowners in the region. Whether deserved or not, they also inherited the resentment and distrust that community members held against patrons for generations. Communities thought the municipal government was unresponsive, arrogant and corrupt. On the other hand, local government officials were frustrated with communities' inability to collaborate and lack of will to participate in planning processes. Village leaders, if they showed up to meetings, sat silently or argued combatively for unrealistic demands. As a result, government 
reforms were not functioning because communities and local government were deadlocked by a combination of mistrust, disdain and inexperience with the new decision-making system.

Could a participatory method like future scenarios bring forest communities and local government together and change their attitudes about each other? Could it teach people how to collaborate constructively and negotiate fairly? Although skeptical at first, the local government and communities agreed to try it out. We first held future scenarios workshops in two communities in the municipality. During each workshop, community members broke into small groups and developed visions of what their community ideally would be like in ten years. The small groups shared their visions and prioritized the most important aspects by voting. Common ideas were clean drinking water, a new schoolhouse, a better road or vegetable gardens. They also discussed how they could prepare for declines in the price of Brazil nut, the primary local income-generating activity. The communities presented their results to the local government. Although government officials were doubtful at the first presentation, by the second meeting the "break-through moment" occurred; the local government officials were surprised by the usefulness of the results and the quality of the presentations. They understood what the communities wanted and could see the potential for improved collaboration. The mayor decided that scenarios could be a way to get the communities involved more productively in the municipal planning process and requested that the workshops be performed in the fifteen communities within the municipality. Once completed, the communities presented their visions at the annual municipal planning meeting (Evans et al., 2008).

During and after the activities, we surveyed participants - both communities and local governments - and external observers for their opinions on the methods. Based on the evaluations and our personal observations, we found that future scenarios methods provided a mechanism for community members to discuss the future and make firm decisions and commitments to address important issues. The scenarios methods helped them articulate their community plans and aspirations to municipal government with specific information that was useful and reasonable. The activities provided a process for community members to think about what they wanted, vote and articulate the results to local governments. The scenarios methods improved communication and most importantly created a process for systematic collaboration between two parties - communities and local government who had previously been unable to work together.

The methods worked because they were systematic, interesting and productive. They generated tangible results in the form of drawings, maps, plans and proposals. They incorporated dynamics to encourage participation and democratic methods such as voting to ensure participation of all community members. The municipal government found the methods effective enough to use as part of its municipal planning process for allocating budgets for community projects (Evans et al., 2008).

Other researchers have assessed the outcomes from the use of future scenarios among forest stakeholders. In all cases, group discussion to assess the methods followed their use, often using a prepared list of questions (e.g. Patel et al., 2006) or relying on invited external observers (Evans et al., 2008). In some examples, participants volunteered comments on the methods (Patel et al., 2006). We compiled our results and those of other researchers and conclude the following:

1. The use of scenarios allowed local stakeholders to develop strategies that encourage self-reliance (Velarde et al., 2007) and strengthen intra-community collaboration (Evans et al., 2006). The concrete products of the scenarios - drawn or written visions, prioritized lists of needs, strategies and proposals - served as records of decision-making processes that validated community proposals (Patel et al., 2006; Kok et al., 2006).

2. Communities started to think about dependency, vulnerabilities and ways to prepare for the future (Velarde et al., 2007) because the methods enhanced community dialogue about diversifying activities and decreasing dependency on a single source of sustenance (Alcamo, 2001; Evans et al., 2006).

3. Scenarios improved organizational capacity, internal democratic processes and planning. The methods strengthened group discussions and broadened participation in decision making and in the development of practical strategies because the methods provided techniques and practical experiences for holding meetings in which all participate (Evans et al., 2006; Velarde et al., 2007).

4. Scenarios improved collaborative planning and negotiation between communities and authorities (Alcamo, 2001; Patel et al., 2006; Evans et al., 2006). They provided a framework for making positions explicit and presenting them for public discussion. The process worked both ways. The communities enhanced negotiations and defended their interests with authorities, but the latter also met obligations under decentralization reforms (CIFOR, 2007).

5. Community leaders became more vocal and assertive in meetings, and marginalized groups within communities, like women or the poor, made their voices heard (Patel et al., 2006; Evans et al., 2008). Exchanges of ideas and the consideration of alternative perspectives took place when explicit efforts were made to share the scenarios produced by different groups. 


\section{Future scenarios' limitations}

While the use of scenarios methods encouraged positive collaboration and negotiations between communities and municipal governments in Bolivia, Zimbabwe and Peru (Evans et al., 2006), we discovered that future scenarios do not work everywhere and in every situation (MEA, 2005; Lynam et al., 2007; CIFOR, 2007). For instance, future scenarios have had less of an impact in Vietnam (Evans et al., 2008) and Indonesia (Wollenberg et al., 2007).

We held workshops in Vietnam with forest communities and government officials as in Bolivia. In Vietnam, after years of management by the state forestry officials, new legislation was enacted to give forest lands to communities under long term contracts (Sikor, 2006). Only a limited portion of forest lands was given to them and even their control over those lands was constrained. Forestry officials and district governments were hesitant to trust communities (Evans et al., 2006). Local forest technicians saw potential in the future scenarios methods for better communication but stopped short of accepting communities as equal partners in related decision making. In this context, the methods facilitated information exchange but fell short of fomenting the type of "breakthrough moment" or a break down of power barriers that led to transformative collaboration between communities and local government witnessed in Bolivia (Evans et al., 2008).

Using future scenarios alone cannot force institutional reform if there is significant resistance. Officials must be positively predisposed to engage with communities. There must be opportunities where minds are receptive to "breakthrough" moments. In a top-down and hierarchical political system such as Vietnam's, where government sinecures encourage complacency and stifle change, participatory methods are of minor use at best and can be manipulative at worse (Mosse, 2001). This broader political context plays a dominant role in the outcome of the use of participatory methods, and hence in the outcome of communal forest management, even under conditions of devolved ownership. In Indonesia, rights to make decisions over local forests granted to communities and district governments shortly after the start of decentralization have subsequently been taken away by central government (Ribot et al., 2006; Wollenberg et al., 2007). The decentralization reforms created a mechanism for communities to participate in district planning, but this mechanism has been ignored by district governments in forest rich regions (CIFOR, 2007).

Apart from the contextual issues, future scenarios have certain structural limitations: their success depends on skilled, trained facilitators who assure productive, focused discussion without discouraging the free expression of ideas. The methods are challenging for inexperienced facilitators who may struggle to maintain the focus on forestry-related issues (Evans et al., 2008). Scenario methods also suffer from what Mosse (2001) contends is a problem with the pub- lic nature of participatory planning: group methods can actually limit participation if marginalized groups or members are intimidated out of fully participating in public meetings.

\section{Conclusions}

Since the 1990s, governments have been handing over tropical forests to local communities under tenure reform on a vast scale. Forest devolution was inspired by principles of social justice, hopes of improving local livelihoods and the urgency to conserve remaining tropical forest. While forest devolution and government decentralization trends in the tropics continue (Ribot et al., 2006), forest communities are frequently unprepared for their new responsibilities and lack democratic decision making practices and capacity inside their organizational structures and forestry decision making forums. Community forest management is viable only when communities can negotiate effectively with government, private enterprise and NGOs and are accepted as equal partners in negotiations and decision making about the forest. While there are examples where local communities have become responsible stewards of forests, there are many other cases where unsustainable forest exploitation has continued unabated or has even been accelerated by forest devolution.

After a decade of experience, we know that there are ways of improving the possibilities of success. Sustainable resource management requires that communities make long term decisions through processes that are equitable and transparent. They need tools that help them formulate their agenda to interact and collaborate with regulatory agencies or other market actors. Future scenarios methods are promising means for assisting forest communities to find common ground, define collective interests, develop the skills and gain the experience they need to take proactive roles and benefit from forest devolution.

The methods cannot guarantee institutional reform, but they can provide a catalyst for generating the dialogue and interactions necessary for fair, transparent and productive collaboration for sustainable forest management. Participatory methods such as future scenarios alone are not sufficient to empower marginalized or remote communities and completely level the playing field with other more powerful players, but they can help prepare communities for the challenges and opportunities of forest devolution.

Edited by: T. Lynam

Reviewed by: two anonymous referees 


\section{References}

Alcamo, J.: Scenarios as tools for international environmental assessments, Environment Issue Report No. 24, Luxembourg, Office for Official Publications of the European Communities, available at: http://www.usf.uos.de/IA/Scenarios_Report. pdf, 2001.

Arnold, J. E. M.: Forests and people: 25 years of community forestry, Rome, FAO, 2001.

Barton, B. D., Merino-Pérez, L., and Barry, D.: The community forests of Mexico. Managing for sustainable landscapes, Austin, University of Texas Press, 2005.

Biermann, F., Campe, S., Jacob, K. (Eds.): Proceedings of the 2002 Berlin conference "Knowledge for the sustainability transition. The challenge for social science", Global Governance Project, Amsterdam, Berlin, Potsdam and Oldenburg, 2004.

Biggs, R., Raudsepp-Hearne, C., Atkinson-Palombo, C., Bohensky, E., Boyd, E., Cundill, G., Fox, H., Ingram, S., Kok, K., Spehar, S., Tengö, M., Timmer, D., and Zurek, M.: Linking futures across scales: a dialog on multiscale scenarios, Ecol. Soc., 12(1), 17, http://www.ecologyandsociety.org/vol12/iss1/art17/, 2007.

Brewer, G. D.: Inventing the future: scenarios, imagination, mastery and control, Sustainability Science, 2, 159-177, 2007.

Buck, L., Geisler, C. C., Schelhas, J., and Wollenberg, E.: Biological diversity: Balancing interests through adaptive collaborative management, Boca Raton, CRC Press, 2001.

Carpenter, S. R., Bennett, E. M., and Peterson, G. D.: Scenarios for ecosystem services: an overview, Ecol. Soc., 11(1), 29, http: //www.ecologyandsociety.org/vol11/iss1/art29/, 2006.

CIFOR: Towards wellbeing and responsive government in forest communities: A source book for local government, Bogor, Indonesia: Center for International Forest Research, 2007.

Chapin, M.: A challenge to conservationists, World Watch Magazine, 17(6), 17-31, 2004.

Colfer, C. and Pierce, J.: The complex forest: Communities, uncertainty and adaptive collaborative management, Washington, RFF Press, 2005.

Colfer, C., Pierce, J., and Byron, Y.: People managing forests: the links between human well-being and sustainability, Bogor, Indonesia, Center for International Forestry Research, 2001.

Cronkleton, P., Taylor, P. L., Barry, D., Stone-Jovicich, S., and Schmink, M.: Environmental governance and the emergence of forest-based social movements, Occasional Paper 49, Bogor, Indonesia, Center for International Forestry Research, 2008.

Davis-Case, D.: The community's toolbox: the idea, methods and tools for participatory assessment, monitoring and evaluation in community forestry, Rome, FAO, 1990.

Edmunds, D. and Wollenberg, E.: Local forest management: the impacts of devolution policies, London, Earthscan Publications, London, 2003.

Enters, T., Durst, P. B., and Victor, M. (Eds.): Decentralization and devolution of forest management in Asia and the Pacific, RECOFTC Report No. 18 and RAP Publication 2000/1, Bangkok, Thailand, 2000.

Evans, K., de Jong, W., Cronkleton, P., and Tran Huu Nghi: Thinking about the future in forest communities: Four participatory methods for planning and decision-making, Society and Natural Resources, accepted, 2008.

Evans, K., Velarde, S. J., Prieto, R. P., Rao, S. N., Sertzen, S., Davila, K., Cronkleton, P., and de Jong, W.: Field guide to the future: four ways for communities to think ahead, Naibori, Center for International Forestry Research, Alternative to Slash and Burn Consortium, World Agroforestry Centre, 2006.

Fahey, L. and Randell, R. M.: Learning from the future: Competitive foresight scenarios, New York, Wiley and Sons, 1997.

Fisher, R.:Collaborative Management of Forests for Conservation and Development, Gland, Switzerland, IUCN and WWF, 1995.

Gottwald, C.: Capacities of rural forest-dependent communities in the northern Bolivian Amazon in times of legal reforms, Freiburger Schriften zur Forst- und Umweltpolitik Band 11, Remagen-Oberwinter, Verlag Dr. Kessel, 2006.

Holman, P. and Devane, T.: The change handbook: group methods for shaping the future, San Francisco, Berrett-Koehler Publishers, 1999.

Kassa, H., Campbell, B., Sandewall, M., Kebede, M., Tesfaye, Y., Dessie, G., Seifu, A., Tadesse, M., Garedew, E., and Sandewall, K.: Building future scenarios and uncovering persisting challenges of participatory forest management: The case of Chilimo Forest in Central Ethiopia, J. Environ. Manage., in press, 2008.

Kok, K., Patel, M., Rothman, D., and Quaranta, R.: Multi-scale narratives from a IA perspective: Part II. Participatory local scenario development, Futures, 38, 285-311, 2006.

Lynam, T., de Jong, W., Sheil, D., Kusumanto, T., and Evans, K.: A Review of tools for incorporating community knowledge, preferences, and values into decision making in natural resources management, Ecology and Society, 12, 5, http://www. ecologyandsociety.org/vol12/iss1/art5/, 2007.

Millennium Ecosystems Assessment: Ecosystems and well-being, Five volume set, Washington, D.C., Island Press, 2005.

Mosse, D.: Peopl's knowledge, participation and patronage: Operations and representations in rural development, in: Participation: The new tyranny?, edited by: Cooke, B. and Kothari, U., London, Zed Books Ltd., 16-35, 2001.

Nemarundwe, N., de Jong, W., and Cronkleton, P.:Future scenarios as an instrument for forest management: Manual for training facilitators of future scenarios, Bogor, Indonesia, Center for International Forestry Research, 2003.

Patel, M., Kok, K., and Rothman, D.: Participatory scenario construction in land use analysis: An insight into the experiences created by stakeholder involvement in the northern Mediterranean, Land Use Policy, 24, 546-561, 2006.

Ribot, J., Agrawal, A., and Larsson, A.: Recentralizing while decentralizing: How natural governments reappropriate forest resources, World Dev., 34, 1864-1886, 2006.

Rights and Resource Initiative: Seeing people through the trees. Scaling up efforts to advance rights and address poverty, conflict and climate change, Washington, D.C., Rights and Resource Initiative, 2008.

Ruiz, S. A.: Institutional change and social conflicts over forest use in the Northern Bolivian Amazon, Remagen-Oberwinter, Germany, Verlag Dr. Kessel, 2005.

Sikor, T.: Analyzing community-based forestry: Local, political and agrarian perspectives, Forest Policy and Econ., 8, 339-349, 2006.

Stearman, A. M.: One step forward, two steps back: The Sirionó and Yuquí community forestry projects in the Bolivian Amazon, Hum. Organ., 65, 156-174, 2006.

Stock, C., Bishop, I. D., and Green, R.: Exploring landscape changes using an envisioning system in rural community work- 
shops, Landscape Urban Plan., 79, 229-239, 2007.

Stocks, A.: Too much for too few: Problems with indigenous land tenure in Latin America, Annual Reviews in Anthropology, 16, 85-104, 2005.

Sunderlin, W. D., Angelsen, A., Belcher, B., Burgers, P., Nasi, R., Santoso, L., and Wunder, S.: Livelihoods, forests, and conservation in developing countries: An overview, World Dev., 33, 1383-1402, 2005.

Sunderlin, W. D., Hatcher, J., and Liddle, M.: From exclusion to ownership? Challenges and opportunities in advancing forest tenure reform, Washington D.C., Rights and Resources Initiative, 2008.

Thongbai, P., Pipattawattanakul, P., Preechapanya, P., and Manassrisuksi, K.: Participatory scenarios for sustainable management of an ASB benchmark site in Thailand: The case of Mae Kong Kha sub-watershed of Mae Chaem watershed, Paper presented at International Symposium "Towards Sustainable Livelihoods and Ecosystems in Mountainous Regions", 7-9 March 2006, Chiang Mai, Thailand, 2006.

van der Heijden, K.: Scenarios: The Art of Strategic Conversation, Chichester, England, John Wiley \& Sons, 1996.
Velarde, S. J., Rao, S., Evans, K., Vandenbosch, T., and Prieto, R.: Preparing for a changing environment: Using scenarios for environmental education, Paper presented to the 4th World Environmental Education Congress, 2-6 July 2007, Durban, South Africa, 2007.

Wack, P.: Scenarios: Uncharted waters ahead, Harvard Business Review, 63(5), 1985.

Wollenberg, E., Edmunds, D., and Buck, L.: Using scenarios to make decisions about the future: Anticipatory learning for the adaptive co-management of community forests, Landscape Urban Plan., 47, 65-77, 1999.

Wollenberg, E., Edmunds, D., and Buck, L.: Anticipating change: Scenarios as a tool for adaptive forest management, Bogor, Indonesia, Center for International Forestry Research, 2000.

Wollenberg, E., Iwan, R., Limberg, G., Moeliono, M., Rhee, S., and Sudana, M.: Facilitating cooperation during times of chaos: spontaneous orders and muddling through in Malinau, Ecol. Soc., 12(1), 3, http://www.ecologyandsociety.org/vol12/ iss 1/art3/, 2007. 